\title{
Determination of Ethyl Carbamate in Alcoholic Beverages and Fermented Foods Sold in Korea
}

\author{
Dayeon Ryu ${ }^{1, \#}$, Bogyoung Choi ${ }^{1, \#}$, Eunjoo Kim', Seri Park', Hwijin Paeng', \\ Cho-il Kim ${ }^{2}$, Jee-yeon Lee ${ }^{3}$, Hae Jung Yoon ${ }^{4}$ and Eunmi Koh ${ }^{1}$ \\ ${ }^{1}$ Department of Food and Nutrition, College of Natural Sciences, Seoul Women's University, Seoul, Korea \\ ${ }^{2}$ Bureau of Health Industry Promotion, Korea Health Industry Development Institute, Chungcheongbuk-do, Korea \\ ${ }^{3}$ Nutrition Policy \& Promotion Team, Korea Health Industry Development Institute, Chungcheongbuk-do, Korea \\ ${ }^{4}$ Department of Food Safety Evaluation, National Institute of Food and Drug Safety Evaluation, \\ Ministry of Food and Drug Safety, Chungcheongbuk-do, Korea
}

(Received August 5, 2015; Revised August 31, 2015; Accepted September 10, 2015)

\begin{abstract}
Ethyl carbamate (EC) classified as a probable human carcinogen (Group 2A) is naturally formed in alcoholic beverages and fermented foods during fermentation process and/or during storage. The objective of this study was to analyze EC in 34 food items including 14 alcoholic beverages and 20 fermented foods sold in Korea. Each food was collected from 18 supermarkets in 9 metropolitan cities in Korea, and then made into composite. According to food composition and alcohol content, samples were divided into four matrices such as apple juice, milk, Soju (liquor containing about 20\% alcohol), and rice porridge. The maximum EC value of $151.06 \mu \mathrm{g} / \mathrm{kg}$ was found in Maesilju (liquor made from Maesil and Soju). Whisky and Bokbunjaju (Korean black raspberry wine) contained $9.90 \mu \mathrm{g} / \mathrm{kg}$ and $6.30 \mu \mathrm{g} / \mathrm{kg}$, respectively. EC was not detected in other alcoholic beverages. Of 20 fermented foods, Japanese-style soy sauce had highest level of $15.59 \mu \mathrm{g} / \mathrm{kg}$ and traditional one contained $4.18 \mu \mathrm{g} / \mathrm{kg}$. Soybean paste had $1.18 \mu \mathrm{g} / \mathrm{kg}$, however, EC was not found in other fermented foods.
\end{abstract}

Key words: Ethyl carbamate, Alcoholic beverage, Fermented foods

\section{INTRODUCTION}

Ethyl carbamate (EC, CAS No. 51-79-6), known as urethane, is an ethyl ester of carbamic acid. It was used as a hypnotic in man and an anesthetic in animals in 1940s. However, it was found to be genotoxic and carcinogenic in 1943 (1). EC is rapidly absorbed from the gastrointestinal tract and the skin, and then distributed in the body (2). In liver, up to $90 \%$ of EC absorbed is hydrolyzed by microsomal esterase and eliminated as ethanol, carbon dioxide, and ammonia (Fig. 1). About 5\% of EC is excreted in the urine

Correspondence to: Eunmi Koh, Department of Food and Nutrition, Seoul Women's University, Hwarang-ro, Nowon-gu, Seoul 139-774, Korea

E-mail: kohem7@swu.ac.kr

"Dayeon Ryu and Bogyoung Choi contributed equally to this work.

This is an Open-Access article distributed under the terms of the Creative Commons Attribution Non-Commercial License (http:// creativecommons.org/licenses/by-nc/3.0) which permits unrestricted non-commercial use, distribution, and reproduction in any medium, provided the original work is properly cited. after hydroxylation and conjugation. EC is also oxidized to vinyl carbamate $(0.5 \%)$ by cytochrome P-450 $2 \mathrm{E} 1$ and further converted into vinyl carbamate epoxide, which can bind covalently to DNA, RNA and proteins. The carcinogenic potential of EC includes gene mutations and DNA damage. Animal studies have shown that EC causes an increase in the incidence of tumors in several tissue sites including lung, liver, and blood vessels (3-5). Consequently, the International Agency for Research on Cancer (IARC) classified EC as a possible human carcinogen (Group 2B) in 1974 (6). Recently, IARC upgraded EC to a probable human carcinogen (Group 2A) in 2007 (7). The concern over the presence of EC and its toxicity in regularly consumed food products and alcoholic beverages has raised global interest to assess the possible risks to human health. The Joint Food and Agriculture Organization/World Health Organization Expert Committee on Food Additive (JECFA) evaluated the exposure to EC in 2005 and concluded that the intake of EC from foods excluding alcoholic beverages would be of low concern (8). However, when both alcoholic beverages and foods were combined, its intake increased about 4-fold and consequently posed potential carcinogenic 


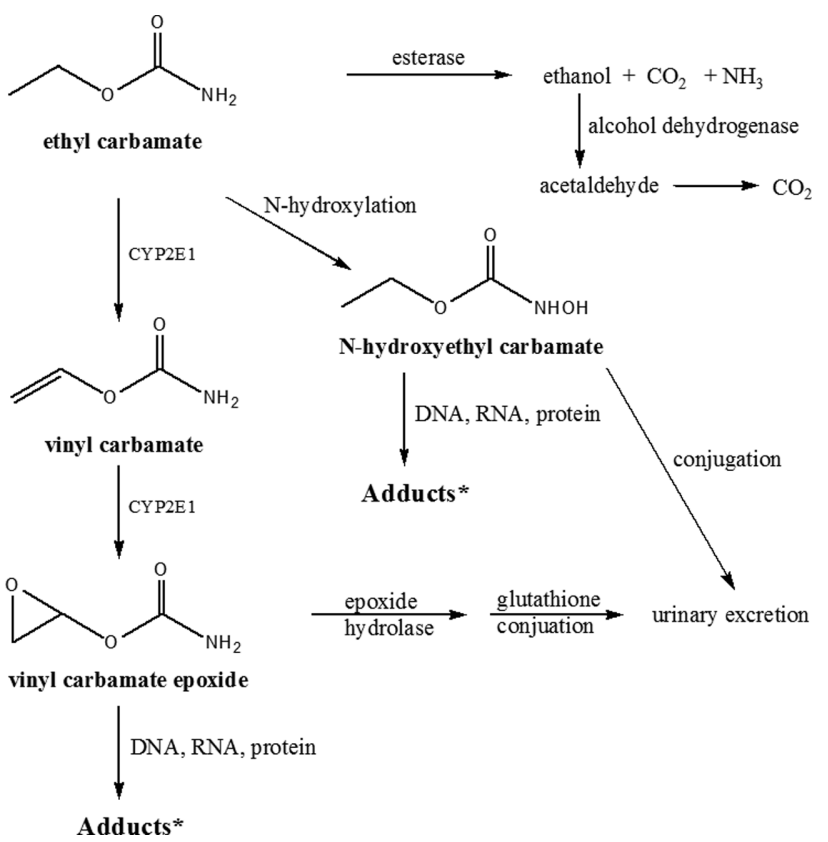

Fig. 1. Probable activation and inactivation pathways of ethyl carbamate metabolism. * Toxic metabolic pathways are indicated by bold type. * Adducts are responsible for the carcinogenic effect.

risks (8).

EC is naturally formed in fermented foods and alcoholic beverages during the fermentation process and/or during storage. Table 1 gives EC levels in alcoholic beverages from China, EU, Hong Kong, Japan, South Korea, and United States. The contents of EC in alcoholic beverages vary over a wide range. The levels of EC in wine ranged from $8 \mu \mathrm{g} / \mathrm{L}$ in white table wine to $111 \mu \mathrm{g} / \mathrm{L}$ in sake (9), and EC concentrations in stone-fruit brandies ranged from 100 to $22,000 \mu \mathrm{g} / \mathrm{kg}(10,11)$. Chinese rice wine contained nearly twice as much as EC than other Chinese alcoholic beverages (12). About $80 \%$ of EC present in spirits was formed during the distillation step and/or within the first $48 \mathrm{hr}$ after distillation (13). In comparison, the contents of EC in beer were lowest, ranging from not-detected (ND) to $5.8 \mu \mathrm{g} / \mathrm{kg}$. The occurrence of EC in fermented foods is shown in Table 2. The highest level of EC, up to $344 \mu \mathrm{g} / \mathrm{kg}$, was found in Chinese red sufu, a fermented soybean curd (14). Toasting bread led to increases of between 3- and 8-fold in EC ranging from 3.5 to $33.8 \mu \mathrm{g} / \mathrm{kg}$ on a wet weight basis $(15,16)$. Azodicarbonamide acts as a dough improver by chemically oxidizing thiol groups and rapidly forming the gluten network in the bread-making industry and as a blowing agent in beer. EC has been shown to form from azodicarbonamide breakdown during baking (17). Soy sauce had a wide range of EC from ND to $108 \mu \mathrm{g} / \mathrm{kg}$. EC was also found in other fermented foods including vinegar, bread, and soybean paste. Generally, the contents of EC in fermented foods
Table 1. Concentrations ( $\mu \mathrm{g} / \mathrm{kg}$ ) of ethyl carbamate in alcoholic beverages

\begin{tabular}{|c|c|c|c|c|}
\hline Country & Product & $\begin{array}{c}\text { No. of } \\
\text { samples }\end{array}$ & $\begin{array}{c}\text { Ethyl } \\
\text { carbamate }\end{array}$ & Reference \\
\hline \multirow[t]{4}{*}{ China } & Beer & 20 & $2-3$ & \multirow[t]{4}{*}{12} \\
\hline & Wine & 30 & $9-34$ & \\
\hline & Rice wine & 92 & $8-515$ & \\
\hline & White spirit & 22 & $12-192$ & \\
\hline \multirow[t]{6}{*}{ EU members } & Beer & 13 & ND-1 & \multirow[t]{6}{*}{11} \\
\hline & Wine & 17 & ND-24 & \\
\hline & Fortified wine & 15 & $14-60$ & \\
\hline & Sake & 2 & $81-164$ & \\
\hline & Stone-fruit brandy & 3,244 & ND-22,000 & \\
\hline & Whisky & 210 & ND-1,000 & \\
\hline \multirow[t]{4}{*}{ Hong Kong } & Beer & 15 & ND-5.8 & \multirow[t]{4}{*}{28} \\
\hline & Wine & 20 & $6.7-47$ & \\
\hline & Rice wine & 21 & $2.0-330$ & \\
\hline & Distilled spirits & 9 & $20-66$ & \\
\hline Japan & Sake & 92 & ND-202 & 11 \\
\hline \multirow[t]{5}{*}{ South Korea } & Distilled spirits & 5 & ND-196 & \multirow[t]{5}{*}{32,56} \\
\hline & Wine & 30 & $2.64 \pm 3.71$ & \\
\hline & Rice wine & 8 & $14.11 \pm 9.58$ & \\
\hline & Liquor & 2 & $157-230$ & \\
\hline & Soju & 6 & ND & \\
\hline \multirow[t]{4}{*}{ United States } & Wine & 91 & ND-254 & \multirow[t]{4}{*}{54} \\
\hline & Sake/rice wine & 34 & $10-904$ & \\
\hline & Whisky & 212 & ND-1,719 & \\
\hline & Brandy & 26 & $9-387$ & \\
\hline
\end{tabular}

Table 2. Concentrations $(\mu \mathrm{g} / \mathrm{kg})$ of ethyl carbamate in fermented foods

\begin{tabular}{llccc}
\hline \hline Country & Product & $\begin{array}{c}\text { No. of } \\
\text { samples }\end{array}$ & $\begin{array}{c}\text { Ethyl } \\
\text { carbamate }\end{array}$ & Reference \\
\hline Canada & Bread & 12 & $1.4-4.8$ & 15 \\
& Toast & 24 & $1.0-29.2$ & \\
China & Soy sauce & 22 & $8-108$ & 12 \\
& Vinegar & 11 & $2-51$ & \\
& Suful & 10 & $12-124$ & \\
& Red sufu & 10 & $87-344$ & \\
EU members & Bakery & 50 & ND-20 & 11 \\
& Fermented sauce & 44 & ND-18 & \\
& Vinegar & 10 & ND-33 & \\
Hong Kong & Bread/rolls/buns & 15 & ND-8.6 & 28 \\
& Soy sauce & 5 & $1.8-17$ & \\
& Vinegar & 18 & ND-37 & \\
Japan & Soy sauce & 26 & ND-35.2 & 38 \\
South Korea & Kimchi & 20 & ND-16.2 & 19 \\
& Soy sauce & 20 & ND-73.3 & \\
& Soybean paste & 7 & ND-7.9 & \\
& Vinegar & 5 & $0.3-2.5$ & \\
\hline
\end{tabular}

${ }^{11} \mathrm{~A}$ cheese-like product that is one of the most popular fermented soybean foods in China. 
Table 3. Maximum levels of ethyl carbamate for alcoholic beverages

\begin{tabular}{lccccr}
\hline \hline Country & Wine & $\begin{array}{c}\text { Fortified } \\
\text { wine }\end{array}$ & $\begin{array}{c}\text { Distilled } \\
\text { spirits }\end{array}$ & Sake & $\begin{array}{c}\text { Fruit } \\
\text { brandy }\end{array}$ \\
\hline Brazil & & & 150 & & \\
Canada & 30 & 100 & 150 & 200 & 400 \\
Czech Republic & 30 & 100 & 150 & 200 & 400 \\
France & & & 150 & & 1,000 \\
Germany & & & & & 800 \\
South Korea & 30 & & & & 1,000 \\
Switzerland & & & & & \\
United States & 15 & 60 & & & \\
\hline
\end{tabular}

Cited from References 11, 13, and 20.

were quite lower than those of alcoholic beverages. It seems that the formation of EC is closely related to the content of ethanol.

Although there are currently no harmonized maximum levels for EC, some countries have established their own criteria (Table 3). Canada firstly introduced maximum limits for EC in alcoholic beverages in 1985 after high levels of $\mathrm{EC}$ were found in alcoholic beverages. The maximum levels were $30 \mu \mathrm{g} / \mathrm{L}$ for wine and $400 \mu \mathrm{g} / \mathrm{L}$ for fruit brandies. The United States has voluntary limits for domestic alcoholic beverages. Canadian guidelines were adopted by other countries such as Czech Republic, Brazil, France, Germany, and Switzerland. South Korea also set the maximum limit of $30 \mu \mathrm{g} / \mathrm{L}$ only for table wine. There are currently no guidelines governing the presence of EC in fermented foods.

In general, most of beverages and foods have various components that can hinder the analysis of EC from matrix, which affect EC analysis. Besides, beverages and foods contain low levels of EC, close to $\mu \mathrm{g} / \mathrm{kg}$ or below detection limit. Accordingly, a number of analytical methods have been developed in various foods and beverages over the past 30 years (Table 4). Carbamate such as propyl carbamate, butyl carbamate, or ${ }^{13} \mathrm{C},{ }^{15} \mathrm{~N}-\mathrm{EC}$ has been used as an internal standard (18-21). However, these standards have different octanol-water partition coefficient from EC. It could lead to the difference in the recoveries between EC and internal standard. Therefore, the deuterated EC $\left(\mathrm{d}_{5}\right.$-EC) is recently used to provide more precise recovery correction (12,22-24). The most traditional extraction method is a liquid-liquid extraction. Methylene chloride is commonly used as the organic solvent since EC is a weak polar compound. Solid-phase extraction (SPE) provides considerable advantages and is applied in the AOAC method (25). Extrelut or Chem-Elut has been found to be the most prevailing sorbent $(15,18,22,26-28)$. In fatty food matrix, SPE was combined with a clean-up step such as the elution with pentane or hexane to eliminate nonpolar compounds (22). Another technique for extracting EC is a solid phase microextraction (23,29-31). It has advantages to reduce time and cost as well as to avoid EC losses. The most widespread method of EC determination is gas chromatography (GC) with polar columns. The applied detection systems include flame ionization detection (FID), electrolytic conductivity detection (ECD), and mass spectrometry (MS). The MS is the most useful and authoritative method for the quantification of EC. Recently, GC-MS-MS has been adopted to improve selectivity, sensitivity, and repeatability for EC determination $(10,24,32)$. High performance liquid chromatography (HPLC) coupled with a fluorescence detector was employed after the derivatization with 9-xanthydrol (33). Fourier transform infrared (FTIR) spectroscopy was also used for determining EC without derivatization (10).

$\mathrm{EC}$ is formed through the reaction from ethanol and cyanate, urea, citrulline, or other N-carbamyl compounds (Fig.

Table 4. Summary of the methodology of ethyl carbamate determination in alcoholic beverages and fermented foods

\begin{tabular}{|c|c|c|c|c|}
\hline \multirow{2}{*}{ Product } & \multirow{2}{*}{ Internal standard } & \multicolumn{2}{|c|}{ Sample preparation } & \multirow{2}{*}{ Detection } \\
\hline & & Liquid-liquid extraction & Solid-phase extraction & \\
\hline Alcoholic beverages & $\begin{array}{l}\text { Methyl carbamate } \\
\text { Propyl carbamate } \\
n \text {-Butyl carbamate } \\
\text { tert-Butyl carbamate } \\
{ }^{13} \mathrm{C},{ }^{15} \mathrm{~N} \text {-Ethyl carbamate } \\
\mathrm{d}_{5} \text {-Ethyl carbamate } \\
\text { Isopropyl carbamate }\end{array}$ & $\begin{array}{l}\text { Extraction with } \mathrm{CH}_{2} \mathrm{Cl}_{2}, \mathrm{CHCl}_{3} \\
\text { or ethyl acetate } \\
\text { Addition of salts }\left(\mathrm{NaCl}, \mathrm{K}_{2} \mathrm{CO}_{3}\right. \\
\left.\text { or } \mathrm{Na}_{2} \mathrm{SO}_{4}\right) \\
\text { Dilution to } 5 \% \text { or } 20 \% \text { alcohol } \\
\text { Removal of ethanol }\end{array}$ & $\begin{array}{l}\text { Chem-Elut or Extrelut } \\
\text { Alumina } \\
\text { Florisil } \\
\text { Headspace solid-phase microex- } \\
\text { traction } \\
\text { Styrenedivinylbenzene copolymer }\end{array}$ & $\begin{array}{l}\text { GC-MS } \\
\text { GC-MS/MS } \\
\text { GC-ECD } \\
\text { GC-NPD } \\
\text { GC-TEA } \\
\text { GC-FID } \\
\text { FTIR-PLS } \\
\text { HPLC/FLD }\end{array}$ \\
\hline Fermented foods & $\begin{array}{l}\text { Propyl carbamate } \\
n \text {-Butyl carbamate } \\
{ }^{13} \mathrm{C},{ }^{15} \mathrm{~N} \text {-Ethyl carbamate } \\
\mathrm{d}_{5} \text {-Ethyl carbamate }\end{array}$ & $\begin{array}{l}\text { Extraction with } \mathrm{CH}_{2} \mathrm{Cl}_{2} \text {, ethyl } \\
\text { acetate or petroleum ether } \\
\text { Removal of nonpolar compounds } \\
\text { with n-pentane or hexane }\end{array}$ & $\begin{array}{l}\text { Chem-Elut or Extrelut } \\
\text { Deactivated alumina } \\
\text { Celite } \\
\mathrm{C}_{18} \\
\text { Florisil }\end{array}$ & $\begin{array}{l}\text { GC-MS/MS } \\
\text { GC-MS } \\
\text { GC-FID }\end{array}$ \\
\hline
\end{tabular}

\footnotetext{
${ }^{1)}$ It was used after the precolumn derivatization with 9-xanthydrol.
} 
Food additive
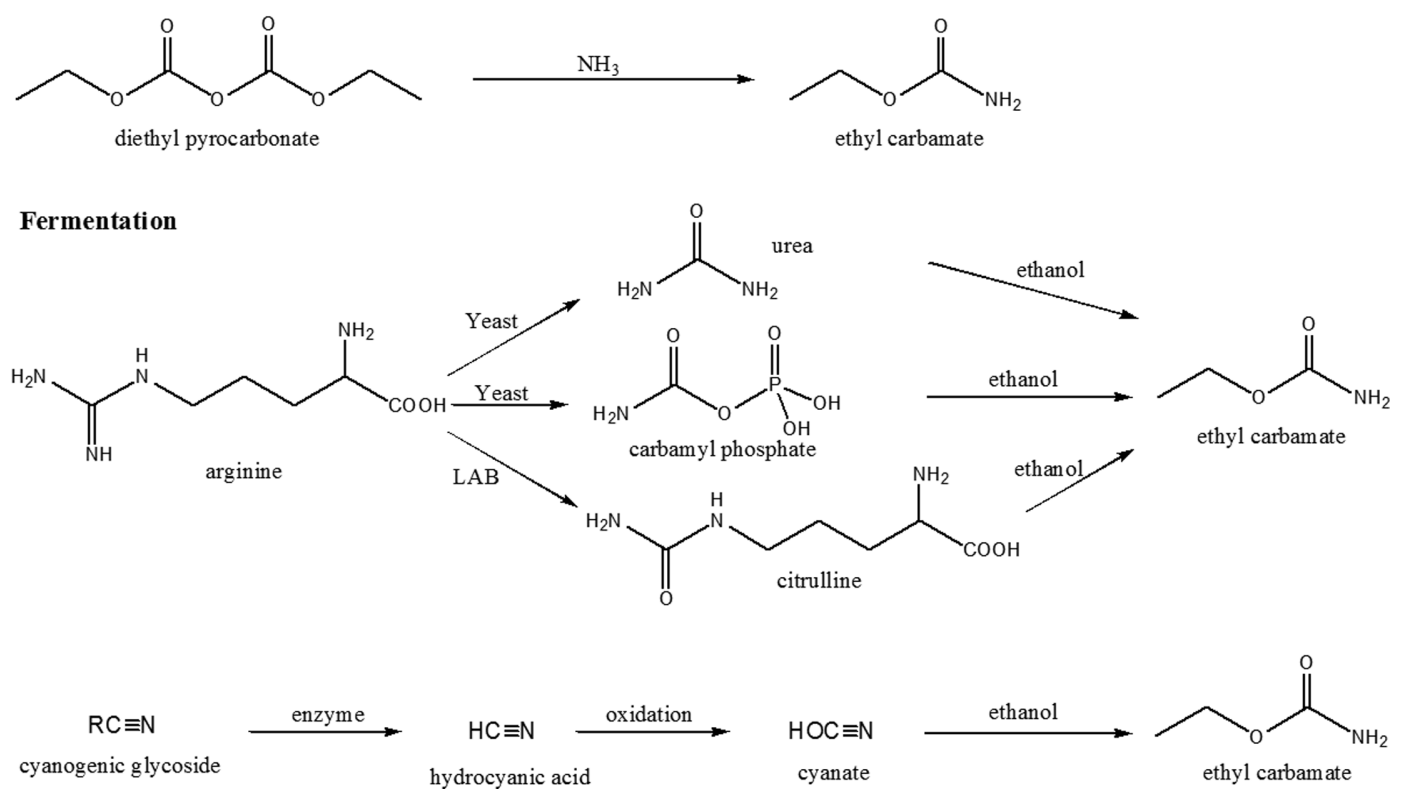

Fig. 2. Mechanism of ethyl carbamate formation in alcoholic beverages and fermented foods. LAB: lactic acid bacteria.

2). Diethyl pyrocarbonate used as an antimicrobial agent added in beer, orange juice, and some soft drinks was found to react with ammonia to form EC in 1971 and then banned in the United States (34). Urea is the most important EC precursor in wine and sake $(35,36)$. It is produced from the arginine metabolism through urea cycle in yeast. Carbamyl phosphate generated from arginine metabolism reacts rap- idly with ethanol to form EC. In addition, citrulline produced through arginine deiminase (ADI) pathway by lactic acid bacteria is another precursor of EC in wine and soy sauce $(37,38)$. Cyanate is a predominant precursor of EC in stone-fruit spirits and other spirits $(13,39,40)$. Cyanogenic glycosides present mostly in the seed of stone-fruits is enzymatically or thermally degraded to hydrocyanic acid, which

Table 5. Approaches to reduce the contents of ethyl carbamate in alcoholic beverages

\begin{tabular}{|c|c|c|}
\hline Product & Method & Reference \\
\hline \multirow[t]{5}{*}{ Wine } & Acid urease & 45 \\
\hline & Addition of diammonium phosphate ${ }^{1)}$ & 57 \\
\hline & Lower temperature & 43 \\
\hline & Lower $\mathrm{pH}$ & 51 \\
\hline & Increase of the expression of $D U R 1,2$ (urea amidolyase) and $D U R 3$ (urea permease) & 50,57 \\
\hline \multirow[t]{4}{*}{ Stone-fruit spirits } & De-stoning prior to mash & 10 \\
\hline & Copper catalyst & 47 \\
\hline & Deletion of $C A R 1$ (arginase) & 48 \\
\hline & Automatic rinsing of the stills/Separation of tailings/non-redistilling tailings & 58 \\
\hline \multirow[t]{4}{*}{ Rice wine/sake } & Refining process of raw materials & 44 \\
\hline & Lower temperature & 14 \\
\hline & Knocking out of CARl (arginase) & 49 \\
\hline & Acid urease & 46 \\
\hline Ume liqueurs & Oxygen absorber/Addition of potassium metabisulfite & 41 \\
\hline \multirow[t]{2}{*}{ Spirits } & Prevention of light exposure/Shorten storage time & 42 \\
\hline & Charcoal filtration & 59 \\
\hline
\end{tabular}

\footnotetext{
${ }^{11}$ It is added to grape must fermentations to alleviate nitrogen deficiency.
} 
is oxidized to cyanate and then reacts with ethanol to form EC (2). A relatively high correlation $(\mathrm{R}=0.597)$ between cyanide and $\mathrm{EC}$ was found in Brazilian sugar cane spirits (13). The addition of potassium metabisulfite inhibited the oxidation of hydrocyanic acid to cyanic acid, which in turn reduced the content of EC in ume, Japanese apricot, liqueur (41). On the other hand, no correlation was found between EC and cyanide in German stone-fruit spirits (10). In addition to these precursors, other factors such as the exposure to UV light, storage time, and fermenting temperature have been known to influence the formation of EC $(10,12,42,43)$.

Numerous methods have been developed to reduce EC level in alcoholic beverages (Table 5). These methods include the use of refined materials, antioxidants, and genetically engineered yeasts. The reduction of EC levels has been achieved mostly by either inhibiting the production of its precursors or decomposing the precursors. Earlier preventive technologies include refining raw materials, removing seed from stone-fruits, controlling temperature and $\mathrm{pH}$, filtering a fermentation product, minimizing exposure to light, and/or shortening storage time (10,42-45). Acid urease was added to hydrolyze urea into carbon dioxide and ammonia in grape wine and rice wine $(45,46)$. Copper catalyst and potassium metabisulfite were used as cyanide catalyst and antioxidant, respectively $(41,47)$. Genetic technologies in modifying fermentation strains provides a significant advance in inhibiting the production of urea or enhancing the metabolism of urea in yeast. The arginase encoded by the CARI gene in yeast degrades arginine into urea (48), which is transported and metabolized by urea amidolayse $(D U R 1,2)$ and urea permease (DUR3) in yeast. Therefore, inhibition of CARI expression and enhancement of DURI,2 and $D U R 3$ expression resulted in the decrease of urea concentrations in sake and grape wine, and consequently reduced the formation of EC $(49,50)$. The utilization of arginine and citrulline via ADI pathway by Lactobaccilus hilgardii $\mathrm{X}_{1} \mathrm{~B}$ and Oenococcus onei could avoid the possibility of EC formation in wine (51).

EC is mainly found in fermented foods and alcoholic beverages. Korean diet includes many fermented foods such as Kimchi and soy sauce. Alcoholic beverages made from grains or fruits are also commonly consumed. For these reasons, the quantification of EC in fermented foods and beverages consumed in the Korean population was needed. Therefore, we determined EC in fermented foods and alcoholic beverages collected from 18 supermarkets in 9 metropolitan cities in Korea.

\section{MATERIALS AND METHODS}

Chemicals. EC, sodium chloride, and sodium hydroxide were purchased from Sigma-Aldrich (St. Louis, MO, USA). Internal standard $\mathrm{d}_{5}$-EC was purchased from CDN isotopes (Pointe-Claire, Quebec, Canada). Methylene chlo- ride and hexane were obtained from J.T. Baker (Center Valley, PA, USA). Disposable diatomite Chem Elut SPE column $(50 \mathrm{~mL})$ was purchased from Agilent Technology (Milwaukee, WI, USA).

Preparation of standard solution. The stock solution of EC $(1000 \mu \mathrm{g} / \mathrm{mL})$ was prepared by dissolving $0.1 \mathrm{~g}$ of $\mathrm{EC}$ in acetone. A working solution $(400 \mathrm{ng} / \mathrm{mL})$ was made by diluting of stock solution in acetone. The $\mathrm{d}_{5}$-EC was prepared with the same method above. For spiking in the sample, internal standard was diluted in distilled water instead of acetone.

Samples. Total 34 food items including 14 alcoholic beverages and 20 fermented foods were chosen from 734 foods appeared in the pooled intake data of 2008, 2009, 2010, and 2011 Korea National Health \& Nutrition Examination Survey (KNHANES). Samples $(500 \sim 800 \mathrm{~g})$ were purchased from 18 supermarkets in 9 metropolitan cities according to a scheme devised by the Korea Health Industry Development Institute (KHIDI) to reflect the market share and population. Samples were pooled to make a composite, homogenized by blending, and then kept at $-20^{\circ} \mathrm{C}$ until analysis.

Determination of ethyl carbamate (EC). EC was determined according to the AOAC official method 994.07 with some modifications (AOAC 1997). The $\mathrm{d}_{5}$-EC was used as the internal standard instead of n-propyl carbamate. GC/MS conditions were revised to separate the $d_{5}$-EC peak from EC peak and shorten a run time. To develop analytical methods depending on food composition, samples were classified into four matrices, which include non-fatty liquid (apple juice), proteinous liquid (milk), alcoholic beverage (Soju, $\sim 20 \%$ ethanol), and non-fatty solid (rice porridge).

Apple juice matrix was firstly neutralized using $1 \mathrm{~N}$ sodium hydroxide solution and then $10 \mathrm{~g}$ of neutralized sample was mixed with $30 \mathrm{~mL}$ of distilled water and then $5 \mathrm{~g}$ of sodium chloride was dissolved in it. After spiked with $100 \mathrm{ng}$ of $\mathrm{d}_{5}-\mathrm{EC}$, it was loaded into a Chem Elut SPE column. After 4 min of equilibration, EC was eluted with $160 \mathrm{~mL}$ of methylene chloride at a rate of 1 drop per second. The eluent was concentrated to about $2 \sim 3 \mathrm{~mL}$ using a rotary evaporator, transferred into v-vial, and further concentrated to $1 \mathrm{~mL}$ under a gentle stream of nitrogen. Each sample was extracted and analyzed by GC-MS in triplicate.

The milk and soju were extracted using the above method with slight modification. Milk was centrifuged to remove proteins before loaded to the SPE column. Soju was diluted into $5 \%$ alcohol content to improve chromatographic resolution.

The rice porridge $(20 \mathrm{~g})$ was mixed with $40 \mathrm{~mL}$ of distilled water and then $\mathrm{d}_{5}$-EC $(50 \mathrm{ng})$ was added. It was stirred for $20 \mathrm{~min}$ and centrifuged at $2000 \mathrm{rpm}$ for $5 \mathrm{~min}$. 
The supernatant was loaded into the Chem Elut column after 4 min of equilibration. EC was eluted with $160 \mathrm{~mL}$ of methylene chloride. The eluent was concentrated to about 2 3 $\mathrm{mL}$ using a rotary evaporator, transferred into v-vial, and further concentrated to $1 \mathrm{~mL}$ under a gentle stream of nitrogen.

A 7820A GC-5977E MS (Agilent Technologies, Santa Clara, CA, USA) was used for the quantification and identification of EC. The GC conditions were as follows: capillary column $30 \mathrm{~m}$ length $\times 0.25 \mathrm{~mm}$ i.d., $0.25 \mu \mathrm{m}$ film thickness DB-WAX (J\&W, Folsom, CA, USA), helium carrier gas at $1 \mathrm{~mL} / \mathrm{min}$, injection volume with $2 \mu \mathrm{L}$ in splitless mode, and injector $210^{\circ} \mathrm{C}$. Oven temperature: $60^{\circ} \mathrm{C}$, $10^{\circ} \mathrm{C} / \mathrm{min}$ to $90^{\circ} \mathrm{C}, 2^{\circ} \mathrm{C} / \mathrm{min}$ to $130^{\circ} \mathrm{C}$ held for $5 \mathrm{~min}, 20^{\circ} \mathrm{C} /$ $\min$ to $220^{\circ} \mathrm{C}$, and then held for $3 \mathrm{~min}$. The MS was operated in the selected ion monitoring (SIM) with electron impact ionization $(70 \mathrm{eV})$. The $\mathrm{MS}$ transfer line and ion source were kept at $240^{\circ} \mathrm{C}$ and $230^{\circ} \mathrm{C}$, respectively. Mass to charge $(\mathrm{m} / \mathrm{z}) 62$ and 64 were major fragment ions of EC and $\mathrm{d}_{5}$-EC. EC was quantified using calibration curves made from peak area ratios of $\mathrm{EC} / \mathrm{d}_{5}-\mathrm{EC}(\mathrm{m} / z 62 \mathrm{vs} m / z 64)$. EC peak was identified by comparing the area ratios of $m / z 62$ vs $m / z 74$ that were major fragment ions of EC.

\section{RESULTS AND DISCUSSION}

Alcoholic beverages. The concentrations of EC in alcoholic beverages are presented in Table 6. Of 14 alcoholic beverages, the maximum value of $151.06 \mu \mathrm{g} / \mathrm{kg}$ was found in Maesilju, followed by whisky $(9.90 \mu \mathrm{g} / \mathrm{kg})$ and

Table 6. Contents of ethyl carbamate in Korean alcoholic beverages

\begin{tabular}{lc}
\hline \hline Product & Ethyl carbamate $(\mu \mathrm{g} / \mathrm{kg})$ \\
\hline Beer, canned & $\mathrm{ND}^{7}$ \\
Beer, PET bottled & $\mathrm{ND}$ \\
Beer, imported & $\mathrm{N}$ \\
Bokbunjaju $^{1)}$ & 6.30 \\
Cheongju $^{2)}$ & $\mathrm{ND}$ \\
Hanbangju $^{3)}$ & $\mathrm{ND}$ \\
Makgeolli $^{4)}$ & $\mathrm{ND}$ \\
Maesilju $^{5)}$ & 151.06 \\
Red wine & $\mathrm{ND}$ \\
Soju $^{6}$ & $\mathrm{ND}$ \\
Wine, red & $\mathrm{ND}$ \\
Wine, white & $\mathrm{ND}$ \\
Wine, sparkling & $\mathrm{ND}$ \\
Whisky & 9.90 \\
\hline
\end{tabular}

\footnotetext{
${ }^{11}$ Korean black raspberry wine.

${ }^{2)}$ Korean rice wine similar to Japanese sake.

${ }^{3}$ Liquor made from rice and oriental medicine.

${ }^{4}$ Korean traditional alcoholic beverage made from rice.

${ }^{5)}$ Liquor made from Maesil and Soju.

${ }^{6}$ Liquor containing about $20 \%(\mathrm{v} / \mathrm{v})$ alcohol.

${ }^{7)}$ Not detected.
}

Bokbunjaju $(6.30 \mu \mathrm{g} / \mathrm{kg})$. Maesilju is a traditional Korean liqueur made out of green Maesil (Japanese apricot, a fruit of Prunus mume). The content of EC $(151.06 \mu \mathrm{g} / \mathrm{kg})$ in Maesilju is close to the high level $(78.18 \pm 63.10 \mu \mathrm{g} / \mathrm{kg})$ reported previously in 7 Maesilju samples (32). Maesil contains high level of cyanogenic glycoside amygdalin (52), which is degraded to hydrocyanic acid and then oxidized to cyanate. The other ingredient of Maesilju is a Soju that is produced by diluting absolute ethanol to contain about $20 \%$ alcohol. Maesil is commonly removed after soaking in Soju for 100 days and the remaining liquid is ripened for several months or longer. It has been known that the concentrations of EC in Maesilju increased up to $216 \mu \mathrm{g} / \mathrm{kg}$ depending on alcohol content, soaking time of Maesil, and fermentation time $(32,53)$. In earlier literatures, high contents of EC have been found in stone-fruit brandies (Table 1). Currently, there is no maximum EC level for Maesilju in Korea. The value of EC in Maesilju exceeds slightly the Canadian limit of $150 \mu \mathrm{g} / \mathrm{kg}$ for fruit brandy. This result indicates that mitigation action to reduce EC levels in Maesilju should be taken.

Whisky has been reported to contain EC ranging from ND to $1,719 \mu \mathrm{g} / \mathrm{kg}(11,32,54)$. The level $(9.9 \mu \mathrm{g} / \mathrm{kg})$ of EC analyzed in this study is in the range of earlier literatures. It is quite lower than maximum permissible limit of $150 \mu \mathrm{g} /$ $\mathrm{kg}$ for distilled spirits established in Canada, Czech Republic, and France. The content $(6.3 \mu \mathrm{g} / \mathrm{kg})$ of EC in Bokbunjaju (Korean black raspberry wine) is comparable to the value $(1.66 \pm 3.41 \mu \mathrm{g} / \mathrm{kg})$ reported by $\mathrm{Kim}$ et al. (32). In other countries, wine has been known to contain a wide range of EC (ND-549 $\mu \mathrm{g} / \mathrm{kg})(11,14,28,54)$. Korean wines were reported to have an average of $2.64 \pm 3.71 \mu \mathrm{g} / \mathrm{kg}$ (32). However, EC was not detected in wine analyzed in this study. Such variations in EC levels in wine are understandable due to differences in the processing conditions, raw materials, yeast, and lactic acid bacteria. EC was also not detected in beer, Soju, Cheongju (Korean rice wine), and Hanbangju (liquor made from rice and oriental medicine), which is close to the values of earlier literatures $(22,32)$.

Fermented foods. The concentrations of EC in fermented foods are shown in Table 7. Of 20 fermented foods analyzed herein, Japanese-style soy sauce had highest content of $15.59 \mu \mathrm{g} / \mathrm{kg}$ and traditional one contained $4.18 \mu \mathrm{g} /$ $\mathrm{kg}$ (Table 7). Soy sauce has been reported to have 8-108 $\mu \mathrm{g} /$ $\mathrm{kg}$ in Chinese samples, ND-35.2 $\mu \mathrm{g} / \mathrm{kg}$ in Japanese samples, and $1.8-17 \mu \mathrm{g} / \mathrm{kg}$ in Hong Kong samples (Table 2). The content $(1.18 \mu \mathrm{g} / \mathrm{kg})$ of EC in soybean paste was in the range of ND-7.9 reported by Kim et al. (55). The concentrations of EC between 1.4 and $4.8 \mu \mathrm{g} / \mathrm{kg}$ were detected in 12 bread samples (15). Azodicarbonamide used as a flour bleaching agent and a dough conditioner has been reported to increase EC levels during baking (16). However, EC was not detected in 3 different breads analyzed in this study 
Table 7. Contents of ethyl carbamate $(\mu \mathrm{g} / \mathrm{kg})$ in Korean fermented foods

\begin{tabular}{lc}
\hline \hline Product & Ethyl carbamate $(\mu \mathrm{g} / \mathrm{kg})$ \\
\hline Bread $^{1)}$ & $\left.\mathrm{ND}{ }^{6}\right)$ \\
Milk bread $^{1)}$ & $\mathrm{ND}$ \\
Corn bread $^{1)}$ & $\mathrm{N}$ \\
Cheonggukjang $^{2)}$ & $\mathrm{ND}$ \\
Cheese $_{\text {Cheese, mozzarella }}$ & $\mathrm{ND}$ \\
Chunjang $^{3)}$ & $\mathrm{ND}$ \\
Kimchi, Chinese cabbage $_{\text {Maesil extract }}{ }^{4}$ & $\mathrm{ND}$ \\
Red pepper paste, regular & $\mathrm{ND}$ \\
Red pepper paste with vinegar & $\mathrm{ND}$ \\
Ssamjang & $\mathrm{ND}$ \\
Soybean paste & $\mathrm{ND}$ \\
Soy sauce, traditional & $\mathrm{N}$ \\
Soy sauce, Japanese-style & 1.18 \\
Vinegar, brewed & 4.18 \\
Vinegar, brewed with persimmon & 15.59 \\
Yogurt, solid type & $\mathrm{ND}$ \\
Yogurt, liquid type & $\mathrm{ND}$ \\
Yogurt, diluted drink & $\mathrm{ND}$ \\
\hline
\end{tabular}

${ }^{1)}$ Ferment their dough with yeast.

${ }^{2)}$ Korean natto.

${ }^{3)}$ Fermented soybean product colored by caramel.

${ }^{4}$ Fermented liquid made from Japanese apricot and sugar.

${ }^{5}$ Mixture of soybean paste, red pepper paste, garlic, and seasoning.

${ }^{6)}$ Not detected.

even though azodicarbonamide is allowed to use in wheat flour products with the maximum limit of $45 \mathrm{mg} / \mathrm{kg}$ in Korea. EC was not detected in cheese, Chunjang (fermented soybean product colored by caramel), Chengggukjang (soybeans fermented with Bacillus subtilis for 2 3 days), Kimchi, Maesil extract, red pepper paste, Ssamjang (mixture of soybean paste, red pepper paste, garlic, and seasoning), vinegar, and yogurt. These results indicate that most of Korean alcoholic beverages and fermented foods contain EC with low levels or below detection limit. Considering the intakes of Maesilju and soy sauce in the Korean population, preventative actions should be taken to reduce the levels of EC.

\section{ACKNOWLEDGEMENTS}

This research was supported by a grant (13162MFDS049) from Ministry of Food and Drug Safety in 2013-2015.

\section{REFERENCES}

1. Nettleship, A., Henshaw, P.S. and Meyer, H.L. (1943) Induction of pulmonary tumors in mice with ethyl carbamate. $J$. Nat. Cancer Inst., 4, 309-331.

2. Zimmerli, B. and Schlatter, J. (1991) Ethyl carbamate: analytical methodology, occurrence, formation, biological activity and risk assessment. Mutat. Res., 259, 325-350.

3. Mirvish, S.S. (1968) The carcinogenic action and metabolism of urethane and N-hydroxyurethane. Adv. Cancer Res., 11, 142.

4. National Toxicology Program. (1983) Report on Carcinogens, Thirteenth Edition: Urethane. Available from: http:// ntp.niehs.nih.gov/ntp/roc/content/profiles/urethane.pdf. Accessed July 20, 2015.

5. Beland, F.A., Benson, R.W., Mellick, P.W., Kovatch, R.M., Roberts, D.W., Fang, J.L. and Doerge, D.R. (2005) Effect of ethanol on the tumorigenicity of urethane (ethyl carbamate) in B6C3F1 mice. Food Chem. Toxicol., 43, 1-19.

6. IARC (International Agency for Research on Cancer). (1974) Urethane. IARC Monogr. Carcinog. Risks Hum., 7, 111-140.

7. IARC (International Agency for Research on Cancer). (2007) International agency for research. 96, alcoholic beverage consumption and ethyl carbamate (urethane) 6-13 February 2007 1-5. World Health Organization, Lyon, France. Available from: http://monographs.iarc.fr/ENG/Meetings/vol96-summary.pdf. Accessed December 102014.

8. FAO/WHO (Food and Agriculture Organisation/World Health Organisation). (2005) Summary and conclusions of the sixtyfourth meeting of the joint meeting of the joint FAO/WHO expert committee of food additives (WHO Food Additives Series 30) world health organisation, Geneva. WHO Tech. Rep. Ser. 928, 1-47. Available from: http://www.who.int/ipcs/food/ jecfa/summaries/en/summary_report_64_final.pdf. Accessed July 252013.

9. Jagerdeo, E., Dugar, S., Foster, G.D. and Schenck, H. (2002) Analysis of ethyl carbamate in wines using solid-phase extraction and multidimensional gas chromatography/mass spectrometry. J. Agric. Food Chem., 50, 5797-5802.

10. Lachenmeier, D.W., Schehl, B., Kuballa, T., Frank, W. and Senn, T. (2005) Retrospective trends and current status of ethyl carbamate in German stone-fruit spirits. Food Addit. Contam., 22, 397-405.

11. EFSA. (2007) Ethyl carbamate and hydrocyanic acid in food and beverages. EFSA J., 551, 1-44.

12. Wu, H., Chen, L., Pan, G., Tu, C., Zhou, X. and Mo, L. (2012) Study on the changing concentration of ethyl carbamate in yellow rice wine during production and storage by gas chromatography/mass spectrometry. Eur. Food Res. Technol., 235, 779-782.

13. Aresta, M., Boscolo, M. and Franco, D.W. (2001) Copper(II) catalysis in cyanate conversion into ethyl carbamate in spirits, and relevant reactions. J. Agric. Food Chem., 49, 2819-2824.

14. Wu, P., Pan, X., Wang, L., Shen, X. and Yang, D. (2012) A survey of ethyl carbamate in fermented foods and beverages from Zhejiang, China. Food Control, 23, 286-288.

15. Sen, N.P., Seaman, S.W., Boyle, M. and Weber, D. (1993) Methyl carbamate and ethyl carbamate in alcoholic beverages and other fermented foods. Food Chem., 4, 359-366.

16. Dennis, M.J., Massey, R.C., Ginn, R., Parker, I., Crews, C., Zimmerli, B., Zoller, O., Rhyn, P. and Osborne, B. (1997) The effect of azodicarbonamide concentrations on ethyl carbamate concentrations in bread and toast. Food Addit. Contam., 14, 95-100.

17. Cañas, B.J., Diachenko, G.W. and Nyman, P.J. (1997) Ethyl carbamate levels resulting from azodicarbonamide use in 
bread. Food Addit. Contam., 14, 89-94.

18. Xia, Q., Yuan, H., Wu, C., Zheng, J., Zhang, S., Shen, C., Yi, B. and Zhou, R. (2014) An improved and validated sample cleanup method for analysis of ethyl carbamate in Chinese liquor. J. Food Sci., 79, 1854-1860.

19. Kim, Y.K., Koh, E., Chung, H.J. and Kwon, H. (2000) Determination of ethyl carbamate in some fermented Korean foods and beverage. Food Addit. Contam., 17, 469-475.

20. Lim, H.S. and Lee, K.G. (2011) Development and validation of analytical methods for ethyl carbamate in various fermented foods. Food Chem., 126, 1373-1379.

21. Canas, B.J., Havery, D.C. and Joe, F.L. Jr. (1988) Rapid gas chromatographic method for determining ethyl carbamate in alcoholic beverages with thermal energy analyzer detection. $J$. Assoc. Off. Anal. Chem., 71, 509-511.

22. Hansnip, S., Crews, C., Potter, N., Christy, J., Chan, D., Bondu, T., Matthews, W., Walters, B. and Patel, K. (2007) Survey of ethyl carbamate in fermented foods sold in the United Kingdom in 2004. J. Agric. Food Chem., 55, 27552759.

23. Lachenmeier, D.W., Nerlich, U. and Kuballa, T. (2006) Automated determination of ethyl carbamate in stone-fruit spirits using headspace solid-phase microextraction and gas chromatography-tandem mass spectrometry. J. Chromatogr. A, 1108, 116-120.

24. Nóbrega, I.C., Pereira, G.E., Silva, M., Pereira, E.V., Medeiros, M.M., Telles, D.L., Albuquerque, E.C. Jr., Oliveira, J.B. and Lachenmeier, D.W. (2015) Improved sample preparation for GC-MS-SIM analysis of ethyl carbamate in wine. Food Chem., 177, 23-28.

25. AOAC. (1997) AOAC official method 944.07: ethyl carbamate in alcoholic beverages and soy sauce. In: AOAC official methods of analysis (17 edition). J. AOAC Int. Gaithersburg, MD, USA, pp. 14-15.

26. Dennis, M.J., Howarth, N., Massey, R.C., Parker, I., Scotter, M. and Startin, J.R. (1986) Method for the analysis of ethyl carbamate in alcoholic beverages by capillary gas chromatography. J. Chromatogr. A, 369, 193-198.

27. Fauhl, C., Catsburg, R. and Wittkowski, R. (1993) Determination of ethyl carbamate in soy sauces. Food Chem., 48, 313316.

28. Tang, A.S., Chung, S.W., Kwong, K., Xiao, Y., Chen, M.Y., Ho, Y.Y. and Ma, S.W. (2011) Ethyl carbamate in fermented foods and beverages: dietary exposure of the Hong Kong population in 2007-2008. Food Addit. Contam. Part B, 4, 195204.

29. Ye, C.W., Zhang, X.N., Gao, Y.L., Wang, Y.L., Pan, S.Y. and Li, X.J. (2012) Multiple headspace solid-phase microextraction after matrix modification for avoiding matrix effect in the determination of ethyl carbamate in bread. Anal. Chim. Acta, 710, 75-80.

30. Zhang, Y. and Zhang, J. (2008) Optimization of headspace solid-phase microextraction for analysis of ethyl carbamate in alcoholic beverages using a face-centered cube central composite design. Anal. Chim. Acta, 627, 212-218.

31. Perestrelo, R., Petronilho, S., Câmara, J.S. and Rocha, S.M. (2010) Comprehensive two-dimensional gas chromatography with time-of-flight mass spectrometry combined with solid phase microextraction as a powerful tool for quantification of ethyl carbamate in fortified wines. The case study of Madeira wine. J. Chromatogr. A, 1217, 3441-3445.

32. Kim, D.H., Jang, H.S., Choi, G.I., Kim, H.J., Kim, H.J., Kim, H.L. and Kim, K.S. (2013) Determination of residue levels of ethyl carbamate in alcoholic beverages by gas chromatography/tandem mass spectrometry. J. Food Hyg. Saf., 1, 63-68.

33. Herbert, P., Santos, L., Bastos, M., Barros, P. and Alves, A. (2002) New HPLC method to determine ethyl carbamate in alcoholic beverages using fluorescence detection. J. Food Sci., 67, 1616-1620.

34. Solymosy, F., Antoni, F. and Fedorcsák, I. (1978) On the amounts of urethane formed in diethyl pyrocarbonate treated beverages. J. Agric. Food Chem., 26, 500-503.

35. Hara, S., Yoshizawa, K. and Nakamura, K.I. (1988) Formation of ethyl carbamate in model alcoholic beverages containing urea or related compounds. Nippon Jozo Kjiokaishi, 83, 57-63.

36. Dahabieh, M.S., Husnik, J.I. and Van Vuuren, H.J. (2010) Functional enhancement of sake yeast strains to minimize the production of ethyl carbamate in sake wine. J. Appl. Microbiol., 109, 963-973.

37. Azevedo, Z., Couto, J.A. and Hogg, T. (2002) Citrulline as the main precursor of ethyl carbamate in model fortified wines inoculated with Lactobacillus hilgardii: a marker of the levels in a spoiled fortified wine. Lett. Appl. Microbiol., 34, 32-36.

38. Matsudo, T., Aoki, T., Abe, K., Fukuta, N., Higuchi, T., Sasaki, M. and Uchida, K. (1993) Determination of ethyl carbamate in soy sauce and its possible precursor. J. Agric. Food Chem., 41, 352-356.

39. Taki, N., Imamura, L., Takebe, S. and Kobashi, K. (1992) Cyanate as a precursor of ethyl carbamate in alcoholic beverages. Jpn. J. Toxicol. Environ. Health, 38, 498-505.

40. Wucherpfennig, K., Clauss, E. and Konja, G. (1987) Formation of ethyl carbamate in alcoholic beverages based on the maraschino cherry. Dtsch. Lebensm. Rundsch., 83, 344-349.

41. Hashiguchi, T., Horii, S., Izu, H. and Sudo, S. (2010) The concentration of ethyl carbamate in commercial ume (Prunus mume) liqueur products and a method of reducing it. Biosci. Biotechnol. Biochem., 74, 2060-2066.

42. Baumann, U. and Zimmerli, B. (1988) Accelerated formation of ethyl carbamate in spirits. Mitt. Geb. Lebensmittelunters. Hyg., 22, 175-185.

43. Hansnip, S., Caputi, A., Crews, C. and Brereton, P. (2004) Effects of storage time and temperature on the concentration of ethyl carbamate and its precursors in wine. Food Addit. Contam., 21, 1155-1161.

44. Yoshizawa, K., Takahashi, K. and Sato, K. (1988) Changes of urea content in rice and sake moromi during sake making process. Nippon Jozo Kyokaishi, 83, 136-141.

45. Arena, M.E. and Manca de Nadra, M.C. (2005) Influence of ethanol and low $\mathrm{pH}$ on arginine and citrulline metabolism in lactic acid bacteria from wine. Res. Microbiol., 156, 858-864.

46. Fidaleo, M., Esti, M. and Moresi, M. (2006) Assessment of urea degradation rate in model wine solutions by urease from Lactobacillus fermentum. J. Agric. Food Chem., 54, 62266235.

47. Kobashi, K., Takebe, S. and Sakai, T. (1988) Removal of urea from alcoholic beverages with an acid urease. J. Appl. Toxicol., 8, 73-74. 
48. Pieper, H.J., Seibold, R., Luz, E. and Jung, O. (1992) Reduction of the ethyl carbamate concentration in manufacture of Kirsch (cherry spirit). Kleinbrennerei, 44, 125-130.

49. Schehl, B., Senn, T., Lachenmeier, D.W., Rodicio, R. and Heinisch, J.J. (2007) Contribution of the fermenting yeast strain to ethyl carbamate generation in stone fruit spirits. Appl. Microbiol. Biotechnol., 74, 843-850.

50. Kitamoto, K., Oda-Miyazaki, K., Gomi, K. and Kumagai, C. (1993) Mutant isolation of non-urea producing sake yeast by positive selection. J. Ferment. Bioeng., 75, 359-363.

51. Coulon, J., Husnik, J.I., Inglis, D.L., van der Merwe, G.K., Lonvaud, A., Erasmus, D.J. and van Vuuren, H.J.J. (2006) Metabolic engineering of Saccharomyces cerevisiae to minimize the production of ethyl carbamate in wine. Am. J. Enol. Vitic., 57, 113-124.

52. Arena, M.E., Saguir, F.M. and Manca de Nadra, M.C. (1999) Ariginine, citrulline and ornithine metabolism by lactic acid bacteria from wine. Int. J. Food Microbiol., 52, 155-161.

53. Bolarinwa, I.F., Orfila, C. and Morgan, M.R. (2014) Amygdalin content of seeds, kernels and food products commerciallyavailable in the UK. Food Chem., 152, 133-139.

54. Hwang, L.H., Kim, A.K., Park, K.A., Kim, J.Y., Hwang, I.S. and Chae, Y.Z. (2009) The effect of raw material, alcohol con- tent, and trans-resveratrol on the formation of ethyl carbamate in plum wine. J. Food Hyg. Saf., 24, 194-199.

55. Battaglia, R., Conacher, H.B. and Page, B.D. (1990) Ethyl carbamate (urethane) in alcoholic beverages and foods: a review. Food Addit. Contam., 7, 477-496.

56. Park, S.K., Yoon, T. and Choi, D. (2008) Analysis of ethyl carbamate in alcoholic beverages. Anal. Sci. Technol., 21, 5357.

57. Adams, C. and van Vuuren, H.J.J. (2010) Effect of timing of diammonium phosphate addition to fermenting grape must on the production of ethyl carbamate in wine. Am. J. Enol. Vitic., 61, 125-129.

58. Weltring, A., Rupp, M., Arzberger, U., Rothenbuecher, L., Koch, H., Sproll, C. and Lachenmeier, D.W. (2006) Ethyl carbamate: analysis of questionnaires about production methods of stone-fruit spirits at German small distilleries. Dtsch. Lebensm. Rundsch., 102, 97-101.

59. Park, S.R., Ha, S.D., Yoon, J.H., Lee, S.Y., Hong, K.P., Lee, E.H., Yeom, H.J., Yoon, N.G. and Bae, D.H. (2009) Exposure to ethyl carbamate in alcohol-drinking and nondrinking adults and its reduction by simple charcoal filtration. Food Control, 20, 946-952. 